\title{
Use of Oyster Shell Ash of Crassostrea spp. in Mass Production of Sanitized Seedlings of Colocasia esculenta L. Schott by the PIF Method and Influence of Some Fertilizers during Their Growth in Acclimation
}

\author{
Astride C. Djeuani1 ${ }^{1,2 *}$, H. D. Mbouobda1,3, 0. Nzie ${ }^{1,4}$, J. K. Ngoï1,5, N. Niemenak1 \\ ${ }^{1}$ Laboratory of Plant Physiology and Biochemistry, Department of Biological Sciences, Higher Teachers' Training College, \\ University of Yaoundé I., Yaoundé, Cameroon \\ ${ }^{2}$ Departments of Biology and Plant Physiology, Faculty of Science, University of Yaoundé I., Yaoundé, Cameroon \\ ${ }^{3}$ Department of Biology, Higher Teachers' Training College, The University of Bamenda, Bamenda, Cameroon \\ ${ }^{4}$ Departments of Microbiology, Faculty of Science, University of Yaoundé I., Yaoundé, Cameroon \\ ${ }^{5}$ Faculty of Agronomy and Agricultural Sciences, University of DSCHANG, Annex of Bafia, Bafia, Cameroon \\ Email: *astride-carole.djeuani@facsciences-uy1.cm, djeuani.uyi@hotmail.com
}

How to cite this paper: Djeuani, A.C., Mbouobda, H.D., Nzie, O., Ngoï, J.K. and Niemenak, N. (2021) Use of Oyster Shell Ash of Crassostrea spp. in Mass Production of Sanitized Seedlings of Colocasia esculenta L. Schott by the PIF Method and Influence of Some Fertilizers during Their Growth in Acclimation. Open Access Library Journal, 8: e8008.

https://doi.org/10.4236/oalib.1108008

Received: September 26, 2021

Accepted: November 26, 2021

Published: November 29, 2021

Copyright $\odot 2021$ by author(s) and Open Access Library Inc.

This work is licensed under the Creative Commons Attribution International License (CC BY 4.0).

http://creativecommons.org/licenses/by/4.0/

\section{(c) (i) Open Access}

\begin{abstract}
The scarcity of Colocasia esculenta L. Schott seeds available to cover the needs of farmers is attributed to the attacks of Phytophthora colocasiae Racib., a causal agent of taro blight. The direct impact of this pathogen is the lack of tubers for consumption and the near disappearance of monoculture taro plantations. To solve this problem, the objective of this work was to realize the mass production of sanitized seedlings of two cultivars of $C$. esculenta using the PIF method and to evaluate the influence of some fertilizers on the growth of these PIF plants during acclimatization. For this purpose, two cultivars (Makoumba and Ehkwan'frè) of $C$. esculenta were used. For each cultivar, 60 corm fragments with a mass of 500g were grown in propagators (absence and presence of oyster shell ash of Crassostrea spp.). Analysis of agronomic parameters was done during two months of culture in the propagators. Weaning of PIF plants was performed at the end of each month. During acclimation, five treatments were applied (control, arbuscular mycorrhizal fungi, Tithonia diversifolia leaf powder, Oyster shell ash and, dried cow dung) and their influence was evaluated on plant growth parameters during three months, then significant differences were identified by ANOVA via the Student Newman and Keuls test at $5 \%$. The results obtained showed that the average number of
\end{abstract}


buds emitted/corm was more significant in the presence of oyster shell ash. From the 120 corm fragments used, a total of 599 PIF plants were produced (246 and 353 PIF plants for the cultivars Makoumba Ehkwan'frè respectively). The maximum number of weaned PIF plants was recorded in the presence of Oyster shell ash. The average size of these plants varied significantly in the propagators depending on the growth substrates. In acclimation, principal component analyses performed showed a positive correlation between average leaf number and average leaf area in plants inoculated with AMFs at the third month of culture. Oyster shell ash propagator amendment stimulated the production of PIF Plants. The PIF technique used boosted seed production 4.99 times from the 120 corm fragments used.

\section{Subject Areas}

Agricultural Engineering

\section{Keywords}

Colocasia esculenta L. Schott, Oyster Shell Ash, PIF Methods, Seed Plants, Acclimation, Fertilization

\section{Introduction}

Taro, Colocasia esculenta L. Schott, is a tuberous plant in the Araceae family, cultivated for its tubers and leaves as a carbon source [1] [2]. Studies have highlighted some antioxidant, nutritional and anti-diabetic properties in C. esculenta. Other properties of the plant are also noted such as strengthening the immune system, lowering blood pressure, reducing weight gain and fatigue, the prevalence of cell damage, strengthening bones and, improving thyroid function [1] [3]. Ranked third among root and tuber crops after cassava and yam [4], this perennial plant of tropical and subtropical regions, is widely distributed in Southeast Asia, East, West, and Central Africa, the Caribbean, and Southeast America [4] [5]. Among the top ten producing countries in 2019, Cameroon ranks second after Nigeria with 1,909,738 tons [4]. However, in Cameroon, as elsewhere in Africa, its cultivation has always been carried out by smallholders, with limited resources and mostly female farmers [6]. The cultivation practice used for a long time has always been the use of corm fragments as seed from one field to another, implying moreover the transfer of pathogens. The arrival of Phytophthora colocasiae, a fungal pathogen responsible for taro blight since the years 2009 of Cameroon [7], remains at the origin of a real problem limiting the cultivation of this plant which is the unavailability of healthy or sanitized seeds. To solve that problem, [8] proposed the production of vitroplants from the micropropagation technique. However, Arano-Avalosa et al. [9], suggested that the use of the temporary immersion system, would not only reduce the costs of the production technique by micropropagation but also produce in large quantities and com- 
mercial scale. It's true that, the ideal is to produce healthy seeds available to farmers, but questions remain. What will be the cost of these seedlings to a farmer or what will be the cost of expenses to cover a hectare? However, the applications of tissue culture by the PIF technique (plants grown from stem fragments) have already been proven in the cultivation of bananas (Musa sp.). The PIF technique is a method for rapid horticultural propagation of in vivo seedlings [10]. It is a technique that can be used to regenerate a young plant from the shoot fragment or to induce the proliferation of secondary buds on either side of the shoot following the removal of the main bud. This method is less costly than in vitro culture techniques and temporary immersion systems, and thus contributes to rapid production of live-plant material; it can be carried out at any season without difficulty [10] [11] [12], requires a reduced production space, contributes to the rapid production of desired varieties, allows the exploitation of the majority of the buds of the plant, (visible or not) and mass production of genetically identical offshoots, in a sanitized environment and within a reduced time. Until now, the culture substrate of this technique has always been the wood chip or sawdust substrate. Ewané et al. [13] and Ewané et al. [14] showed that it was possible to fertilize this substrate by adding Tithonia diversifolia leaf powder and clamshell powder during the production of PIF plants in bananas.

Oyster shell ash is increasingly used in agriculture as a fertilizer due to its ability to stimulate growth in plants [15] [16]. The role of oyster shell ash of Crassostrea spp. in protecting and strengthening the immune system of plants against some pathogens such as Phytophtora megakarya is recognized [16]. Similarly, their application in Abelmoschus esculentus plants influenced growth, total dry matter content, photosynthetic capacity and, chlorophyll content in its leaves [15]. The mineral and organic compositions of these oyster shells make them undeniably important agronomically. They are important sources of chitin and calcium oxide, which are molecules that play an important role in plant growth promotion [17]. These shells also contain proteins and inorganic salts. Its partially deacetylated form is chitosan (polysaccharide derived from chitin). Their polycationic characters allow them to have several antimicrobial and eliciting properties of defense reactions in the plant [18]. Moreover, Djeuani et al. [19], showed that the presence of chitosan in the culture substrate stimulated both the activation of defense mechanisms and also, the growth in plants of the family Araceae like $X$. sagittifolium. Therefore, what will be the response of taro corms to fertilization with oyster shell powder during the production of mass sanitized seedlings by the PIF method? Similarly, once produced, will these PIF plants be able to respond positively to fertilization? It is in this line that the work aimed to carry out mass production of seedlings sanitized of two varieties of $C$. esculenta widely cultivated in Cameroon by the method of PIF while emphasizing the aspect of fertilization of the propagators of production starting from the ash of the shells of oysters (Crassostrea spp). In addition, a follow-up of the influence of some fertilizers during the growth of these PIF seedlings in acclimatization was 
carried out for the evaluation of their influence on growth.

\section{Material and Methods}

\subsection{Material}

The plant material used for this study was corm fragments of C. esculenta. These corm fragments were collected from C. esculenta plants ranging in age from 9 to 12 months, in a farmer's field in the locality of Santchou, located in the Department of Haut-Nkam, West Region, Cameroon. Each corm fragment weighed $500 \mathrm{~g}$ and two cultivars of $C$. esculenta were used (60 corm fragments for each). The cultivar Makoumba (susceptible to Phytophthora colocasiae attack) and the cultivar Ehkwan'frè (resistant to Phytophthora colocasiae attack).

\subsubsection{Construction of Propagators for the Production of PIF Plants of C. esculenta}

The experimental units were represented by propagators in which corms were placed. Under a shaded area, propagators were built with wooden boards. Each propagator was $5 \mathrm{~m}$ long, $2 \mathrm{~m}$ wide and, $50 \mathrm{~cm}$ deep. These propagators were topped with a $2 \mathrm{~m}$ high stake to facilitate the covering of the device with transparent white plastic. Each propagator was filled as follows from inside to outside; $10 \mathrm{~cm}$ of coarse sand (to facilitate aeration and water circulation in the propagator) and $35 \mathrm{~cm}$ of the growing medium. For the two cultivars of C. esculenta used, four propagators were constructed, two propagators per cultivar.

\subsubsection{Growing Medium}

This was a mixture of wood shavings + sawdust at a ratio of 2:1. The nature of this growing medium varied according to the treatments applied. Two treatments were used per cultivar for the production of PIF plants of C. esculenta. The control treatment (Growing medium made up of the mixture of shavings + sawdust) and the Oyster shell ash treatment (Growing medium made up of the mixture of shavings + sawdust $+1 \mathrm{~kg}$ of Oyster shell ash (Crassostrea spp.)). The culture substrate of each propagator was watered with $10 \mathrm{~L}$ of tap water $48 \mathrm{~h}$ before seeding.

\subsection{Methods}

\subsubsection{Production of Sanitized Seedlings in Both Cultivars of $C$. esculenta by the PIF Method}

1) Disinfection of corm fragments of $C$. esculenta

Corm fragments from each cultivar were stripped of their roots and then trimmed with a knife. The trimming here consisted of removing the dead leaf sheaths and cleaning the fragments from the soil. These cleaned fragments, were soaked in a $30 \% \mathrm{o}(\mathrm{g} / \mathrm{L})$ sodium hypochlorite $(\mathrm{NaClO})$ solution for $40 \mathrm{~min}$. Three rinses were performed at 10,15, and 30 minutes respectively. These disinfected corm fragments were spread on a disinfected stable for $24 \mathrm{~h}$ before seeding.

2) Seeding of corm fragments of $C$. esculenta

Before seeding, the first leaf sheath of the corm was removed. Disinfected 
corm fragments with a weight of $500 \mathrm{~g}$ were used for seeding. A right-angled cross incision was also made on the main bud to destroy its apical dominance. The seeding consisted by placing these fragments of disinfected corms in the different propagators. These fragments of corms were distant at $50 \mathrm{~cm}$ at a right angle, then covered completely with the substrate. The frequency of watering of the seeded propagators was $10 \mathrm{~L}$ of tap water after $72 \mathrm{~h}$.

\subsubsection{Evaluation of Growth and Agronomic Parameters in the Propagators and Weaning of the Produced PIF Plants}

To evaluate the growth of corm fragments after seeding in the propagators, the following parameters were evaluated; number of buds that budded, percentage of bud break, average number of buds that budded/corm, and total number of buds emitted. Other agronomic growth parameters such as average plant size, average number of leaves, average leaf area, average crown diameter and average number of petioles were determined. In addition, the number of weaned plants was evaluated each month for two months. Weaning consisted in detaching the PIF plant of $C$. esculenta produced from the corm fragment with a knife. These weaned seedlings were then put in acclimatization under a shade house.

\subsubsection{Acclimatization of PIF Seedlings of $C$. esculenta}

1) Evaluation of the action of some fertilizers on the growth of PIF plants in acclimatization

The weaned PIF seedlings of $C$. esculenta were acclimated in the shade for three months. These PIF seedlings of the two cultivars of $C$. esculenta were grouped into five treatments: the control consisting of sterile black soil substrate (BS), sterile black soil substrate + arbuscular mycorrhizal fungi (BSAMF), sterile black soil substrate + Tithonia diversifolia leaf powder (BSTD), sterile black soil substrate + oyster shell ash of Crassostrea spp. (BSOS) and sterile black soil substrate + dried powder of cow dung (BSCD). For each treatment, 30 PIF plants of each cultivar were used for a total of 150 PIF plants/cultivar and 300 PIF plants in total. In addition, $900 \mathrm{~g}$ of each treatment was applied at a rate of $30 \mathrm{~g}$ of the treatment to be applied/PIF plant. The plants were watered every $48 \mathrm{~h}$. During growth, the success and mortality rates of PIF plants were evaluated. Each month for three months, the effect of the applied treatments was evaluated on the agronomic growth parameters in the two cultivars used.

\section{2) Statistical analysis}

The results obtained were subjected to a descriptive analysis (Mean \pm standard deviation) and presented in the form of tables (Microsoft Excel 2016 software). The IBM SPSS Version 20.0 software was used to compare the means by an analysis of variance (ANOVA) using the Student-Newman-Keuls test at the 5\% threshold. The principal component analysis (PCA) was used to present in a two-dimensional plan, the arrangement of agronomic growth parameters evaluated according to the treatments during acclimatization using the XLSTAT 2007 Software. Lnk Version 10.0. 


\section{Results}

\subsection{Evaluation of the Number of Corms Having Budded according to the treatments}

All corms grew in the propagator containing substrate and substrate plus oyster shell ash of Crassostrea spp. showed a high bud break rate. A bud break rate of $100 \%$ for corm fragments grown in propagators containing substrate only (cultivar Ehkwan'frè) and substrate + oyster shell ash of Crassostrea spp. (cultivars Makoumba and Ehkwan'frè) was achieved (Table 1). The death of the corm fragment during growth was also noted in cultivar Makoumba has grown only on the substrate, with a percentage of $97 \%$ for 29 corms that budded. The average number of buds emitted per corm was more significant $(\mathrm{P}<0.05)$, in corm fragments grown in propagators with the presence of oyster shell ash of Crassostrea spp. in both cultivars. Bud recovery during bud break of seeded corm fragments varied from fragment to fragment (Figure 1(A) and Figure 1(B)). These buds evolved by forming first leaf sheaths, then well differentiated plants (Figures $1(\mathrm{C})-(\mathrm{F})$ ). This recovery was $06.63 \pm 0.74$ and $07.48 \pm 0.94$ buds respectively in both cultivars. The total number of buds emitted was higher in Makoumba and Ehkwan'frè cultivars grown in the presence of oyster shell ash of Crassostrea spp. (236 and 253 buds emitted respectively) (Table 2).

Table 1. Evaluation of the number of corms that have budded according to the treatments applied.

\begin{tabular}{|c|c|c|c|c|c|c|}
\hline \multirow[b]{2}{*}{ Cultivars } & \multirow[b]{2}{*}{ Treatments } & \multirow[b]{2}{*}{$\begin{array}{l}\text { Number of } \\
\text { corms used }\end{array}$} & \multicolumn{4}{|c|}{ Parameters evaluated } \\
\hline & & & $\begin{array}{l}\text { Number of dead } \\
\text { corms }\end{array}$ & $\begin{array}{l}\text { Number of corms } \\
\text { that budded }\end{array}$ & $\begin{array}{l}\text { Percentage of } \\
\text { bud break (\%) }\end{array}$ & $\begin{array}{c}\text { Average number } \\
\text { of Buds } \\
\text { emitted/Rh }\end{array}$ \\
\hline \multirow{2}{*}{ Makoumba } & Substrate & 30 & 1 & 29 & 97 & $05.16 \pm 0.85 a$ \\
\hline & Substrate + oyster shell & 30 & 0 & 30 & 100 & $06.63 \pm 0.74 b$ \\
\hline \multirow{2}{*}{ Ehkwan'frè } & Substrate & 30 & 0 & 30 & 100 & $06.70 \pm 0.87 \mathrm{a}$ \\
\hline & Substrate + oyster shell & 30 & 0 & 30 & 100 & $07.48 \pm 0.94 b$ \\
\hline
\end{tabular}

*Values with the same letter in the same column are not significant at $5 \%$ to the Student's Newman and Keuls test.

Table 2. Evaluation of the number of PIF plants of $C$. esculenta produced according to the treatments applied.

\begin{tabular}{|c|c|c|c|c|c|c|c|c|}
\hline \multirow[t]{2}{*}{ Cultivars } & \multirow[t]{2}{*}{ Treatments } & \multirow{2}{*}{$\begin{array}{l}\text { Number } \\
\text { of corms used }\end{array}$} & \multirow{2}{*}{$\begin{array}{l}\text { Weight of } \\
\text { a corm }(\mathrm{g})\end{array}$} & \multirow{2}{*}{$\begin{array}{l}\text { Total } \\
\text { number } \\
\text { of Buds } \\
\text { emitted }\end{array}$} & \multicolumn{2}{|c|}{$\begin{array}{l}\text { Number of weaned } \\
\text { plants/Month }\end{array}$} & \multirow{2}{*}{$\begin{array}{l}\text { Number of } \\
\text { PIF plants } \\
\text { weaned } \\
\text { /treatments }\end{array}$} & \multirow{2}{*}{$\begin{array}{c}\text { Total number } \\
\text { of PIF plants } \\
\text { weaned/ } \\
\text { cultivars }\end{array}$} \\
\hline & & & & & Month 1 & Month 2 & & \\
\hline \multirow[b]{2}{*}{ Makoumba } & Substrate & 30 & 500 & 186 & 69 & 37 & 106 & \multirow[b]{2}{*}{246} \\
\hline & $\begin{array}{l}\text { Substrate }+ \\
\text { oyster shell }\end{array}$ & 30 & 500 & 236 & 98 & 42 & 140 & \\
\hline \multirow[b]{2}{*}{ Ehkwan'frè } & Substrate & 30 & 500 & 201 & 86 & 67 & 153 & \multirow[b]{2}{*}{353} \\
\hline & $\begin{array}{l}\text { Substrate + } \\
\text { oyster shell }\end{array}$ & 30 & 500 & 253 & 106 & 94 & 200 & \\
\hline
\end{tabular}



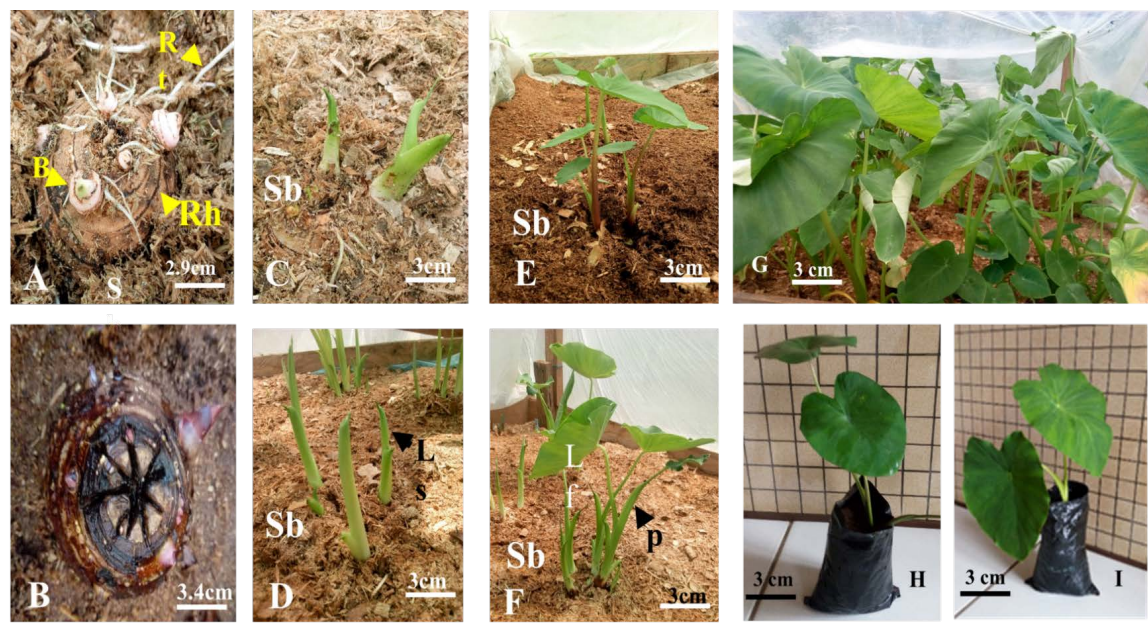

Figure 1. Growth stage of Colocasia esculenta L. Schott seedlings using the PIF method. Fragment of corms that have budded (A) and (B), development of leaf sheaths (C) and (D), well differentiated PIF seedlings: Makoumba (E) and Ehkwan'frè (F), plants ready to be weaned $(\mathrm{G})$ and weaned and acclimatized plants: Makoumba $(\mathrm{H})$ and Ehkwan'frè $(\mathrm{I})$. Buds (B), leaf (Lf), leaf sheath (Ls), petioles (P), roots (Rt), corm (Rh) and substrate (Sb).

\subsection{Number of PIF Seedlings of C. esculenta Weaned according to Treatments Applied}

The number of PIF seedlings weaned varied according to the treatments applied (Table 2). From the 120 corm fragments used, 599 PIF plants were produced after two months of cultivation in both cultivars. The number of weaned PIF plants was very high in Ehkwan'frè with 353 PIF plants compared to Makoumba (246 PIF plants). In both cultivars, the number of PIF plants produced decreased over time (Table 2). For the two weanings carried out during the production of PIF plants, the maximum number of PIF plants produced and weaned was recorded at the first weaning (Table 2). It was 69 and 98 in the cultivar Makoumba and 86 and 106 in the cultivar Ehkwan'frè, respectively for the substrate and substrate + oyster shells of Crassostrea spp. It is also noticed that at the second weaning, the maximum number of PIF plants weaned was 94 PIF plants in the cultivar Ehkwan'frè. However, in the presence of oyster shell ash of Crassostrea spp., the total number of PIF plants was always higher with 140 and 200 PIF plants in the cultivars Makoumba and Ehkwan'frè respectively.

\subsection{Agronomic Parameters of PIF Seedling Growth of $C$. esculenta during Weaning}

The results of the evaluation of agronomic parameters during the growth of PIF plants in propagators varied significantly according to the treatments applied (Table 3). In both cultivars used, average plant height, average collar diameter, the average number of leaves and, average leaf surface were higher and significant $(\mathrm{P}<0.05)$ in propagators fertilized with oyster shell ash of Crassostrea spp. These growth parameters were very high in the first month of growth $\left(1^{\text {st }}\right.$ weaning), with maxima of $40.04 \pm 02.32 \mathrm{~cm}, 04.40 \pm 00.54$ and, $80.68 \pm 12.68 \mathrm{~cm}^{2}$ in 
Table 3. Evaluation of agronomic growth parameters of $C$. esculenta PIF plants during weaning in the two cultivars in Month 1 and Month 2 according to the treatments applied in the propagators.

\begin{tabular}{|c|c|c|c|c|c|c|}
\hline Cultivars & Time & Treatments & $\begin{array}{l}\text { Average plant } \\
\text { height }(\mathrm{cm}) \\
\quad(\mathrm{Std})\end{array}$ & $\begin{array}{l}\text { Average collar } \\
\text { diameter }(\mathrm{cm}) \\
(\mathrm{Std})\end{array}$ & $\begin{array}{l}\text { Average number } \\
\text { of leaves } \\
\text { (Std) }\end{array}$ & $\begin{array}{l}\text { Average leaf } \\
\text { surface }\left(\mathrm{cm}^{2}\right) \\
(\mathrm{Std})\end{array}$ \\
\hline \multirow{7}{*}{ Makoumba } & \multirow{2}{*}{ Month 1} & Substrate & $\begin{array}{c}26.29^{c} \\
(01.41)\end{array}$ & $\begin{array}{c}02.37^{\mathrm{a}} \\
(00.22)\end{array}$ & $\begin{array}{l}03.80^{\mathrm{ab}} \\
(00.44)\end{array}$ & $\begin{array}{c}79.72^{b} \\
(06.33)\end{array}$ \\
\hline & & Substrate + oyster shells & $\begin{array}{l}40.04^{\mathrm{d}} \\
(02.32)\end{array}$ & $\begin{array}{c}02.85^{\mathrm{a}} \\
(00.17)\end{array}$ & $\begin{array}{c}04.40^{\mathrm{b}} \\
(00.54)\end{array}$ & $\begin{array}{c}80.68^{b} \\
(12.68)\end{array}$ \\
\hline & \multirow{5}{*}{ Month 2} & Substrate & $\begin{array}{c}15.99^{a} \\
(01.19)\end{array}$ & $\begin{array}{c}02.56^{\mathrm{a}} \\
(00.28)\end{array}$ & $\begin{array}{c}03.40^{\mathrm{a}} \\
(00.54)\end{array}$ & $\begin{array}{c}51.69^{\mathrm{a}} \\
(07.05)\end{array}$ \\
\hline & & Substrate + oyster shells & $\begin{array}{c}21.60^{\mathrm{b}} \\
(01.67)\end{array}$ & $\begin{array}{c}02.36^{\mathrm{a}} \\
(00.44)\end{array}$ & $\begin{array}{l}03.60^{\mathrm{ab}} \\
(00.54)\end{array}$ & $\begin{array}{l}65.24^{\mathrm{ab}} \\
(09.56)\end{array}$ \\
\hline & & Maen & 26.35 & 02.54 & 03.80 & 69.38 \\
\hline & & $\mathbf{F}$ & 08.02 & 00.20 & 00.14 & 00.61 \\
\hline & & $\mathbf{P}$ & $00.01^{*}$ & $00.65 \mathrm{~ns}$ & $00.70 \mathrm{~ns}$ & $00.44 \mathrm{~ns}$ \\
\hline \multirow{7}{*}{ Ehkwan'frè } & \multirow{2}{*}{ Month 1} & Substrate & $\begin{array}{l}29.29^{b} \\
(01.54)\end{array}$ & $\begin{array}{l}02.77^{b} \\
(00.15)\end{array}$ & $\begin{array}{l}02.80^{\text {ab }} \\
(00.44)\end{array}$ & $\begin{array}{l}131.38^{b} \\
(10.38)\end{array}$ \\
\hline & & Substrate + oyster shells & $\begin{array}{c}40.79^{c} \\
(00.94)\end{array}$ & $\begin{array}{l}02.91^{\mathrm{b}} \\
(00.10)\end{array}$ & $\begin{array}{c}03.20^{\mathrm{b}} \\
(00.54)\end{array}$ & $\begin{array}{l}174.81^{\mathrm{c}} \\
(17.81)\end{array}$ \\
\hline & \multirow{5}{*}{ Month 2} & Substrate & $\begin{array}{c}22.46^{\mathrm{a}} \\
(01.60)\end{array}$ & $\begin{array}{c}02.35^{\mathrm{a}} \\
(00.24)\end{array}$ & $\begin{array}{c}02.20^{\mathrm{a}} \\
(00.44)\end{array}$ & $\begin{array}{c}99.72^{\mathrm{a}} \\
(07.90)\end{array}$ \\
\hline & & Substrate + oyster shells & $\begin{array}{l}26.21^{\mathrm{b}} \\
(02.63)\end{array}$ & $\begin{array}{c}02.79^{b} \\
(00.13)\end{array}$ & $\begin{array}{l}02.60^{\mathrm{ab}} \\
(00.44)\end{array}$ & $\begin{array}{l}110.93^{\mathrm{a}} \\
(17.09)\end{array}$ \\
\hline & & Maen & 29.69 & 02.70 & 02.70 & 129.21 \\
\hline & & $\mathrm{F}$ & 06.45 & 03.19 & 00.17 & 00.24 \\
\hline & & $\mathbf{P}$ & $00.02^{*}$ & $00.09^{*}$ & $00.67 \mathrm{~ns}$ & $00.06^{*}$ \\
\hline
\end{tabular}

Values followed by the same letter for the same parameter are not significantly different according to the Student Newman and Keuls Test at 5\%. ns: not significant at the 5\% level, ${ }^{*}$ : significant at the 5\% level. Std: standard division.

the cultivar Makoumba and $40.79 \pm 00.94 \mathrm{~cm}, 03.20 \pm 00.54$ and, $174.81 \pm 17.81$ $\mathrm{cm}^{2}$ in the cultivar Ehkwan'frè respectively for the average plant height, the average number of leaves and average leaf surface assessed. There was a non-significant effect between the parameters average collar diameter, the average number of leaves, and average leaf surface in the variety Makoumba (Table 3). There was a decrease in the agronomic parameters evaluated between the two weanings carried out in the presence of the substrate and substrate + oyster shells ash of Crassostrea spp. treatments. Also, these agronomic parameters were significantly influenced during growth in the cultivar Ehkwan'frè (Table 3 ).

\subsection{Evaluation of the Growth of PIF Plants of $C$. esculenta during Acclimatization}

Agronomic parameters recorded during acclimation of weaned PIF plants varied 
according to the treatments applied. The average height of $C$. esculenta PIF plants varied over time. In Makoumba's cultivar, the average height of the plant was $22.63 \pm 02.63$ and $24.02 \pm 02.48 \mathrm{~cm}$ during the first two months of growth in weaned PIF plants amended with oyster shell ash of Crassostrea spp., and 24.22 $\pm 05.45 \mathrm{~cm}$ in weaned PIF plants inoculated with AMF in the second month of culture (Figure 2). However, in Ehkwan'frè cultivar, it was $38.30 \pm 03.61 \mathrm{~cm}$ after one month in the presence of oyster shell ash of Crassostrea spp., and in the $3^{\text {rd }}$ month of culture, it was $47.58 \pm 04.32 \mathrm{~cm}$ in the PIF plants of Ehkwan'frè cultivar inoculated with AMFs. The applied fertilizers did not significantly influence the average diameter of the collar of the PIF plants. Similarly, the average number of leaves increased over time. At the third month of cultivation, it was $04.60 \pm 00.34$ and $04.60 \pm 00.54$ for PIF plants amended and inoculated with Tithonia diversifolia leaf powder and AMF, respectively, for PIF plants of Makoumba cultivar and $02.60 \pm 0.54$ for PIF plants inoculated with AMF for PIF plants of Ehkwan'frè cultivar. However, the mean leaf area was positively influenced in C. esculenta PIF plants of both cultivars in the presence of oyster shell ash of Crassostrea spp., and was $120.57 \pm 12.50 \mathrm{~cm}^{2}$ for PIF plants of Makoumba cultivar and $169.86 \pm 14.79$ and $163 \pm 11.90 \mathrm{~cm}^{2}$ during the first two months of cultivation for PIF plants of Ehkwan'frè cultivar.

Principal component analysis (PCA) of the data on the effect of applied treatments between the different agronomic growth parameters over time varied in the two cultivars used (Figure 3(a) and Figure 3(b)). From the analysis of the factorial diagram obtained, there is a positive and significant correlation between the average leaf area and the average number of leaves in PIF plants inoculated with AMFs at the third month of cultivation for both cultivars (Figure 3(a)). Similarly, oyster shell ash of Crassostrea spp. and AMF treatments applied influenced the mean size of PIF plants at the first and second months of growth for the cultivar Makoumba and at the third month for the cultivar Ehkwan'frè.

\section{Discussion}

The objective of this work was mass produce seeds of sanitized plants of two cultivars of $C$. esculenta widely grown in Cameroon by the PIF method. The results obtained varied significantly according to the cultivars used and the treatments.

The percentage of bud break of corm fragments of C. esculenta in both cultivars used was $100 \%$ except in the substrate treatment of Makoumba' cultivar. The death of the observed corm fragment could be related to its physiological state or to the physiological stress caused during the realization of the right-angle cross incision to destroy the apical dominance of the main bud. The number of buds emitted was higher in Ehkwan'frè cultivar compared to Makoumba cultivar (Table 4). This number of buds was also more significant in the presence of oyster shell ash of Crassostrea spp. in the propagator. Moreover, it should be noted that the sawdust substrate used is a lignocellulosic material with a $\mathrm{C} / \mathrm{N}$ ratio between $100-500$ and therefore would be less rich in mineral elements. 


\section{Avg. height of PIF Plants (cm)}

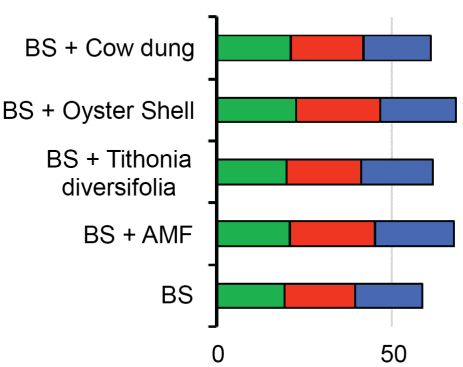

(a)

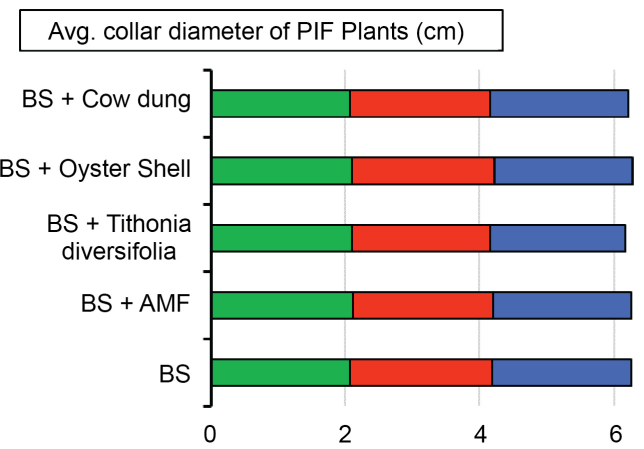

(c)

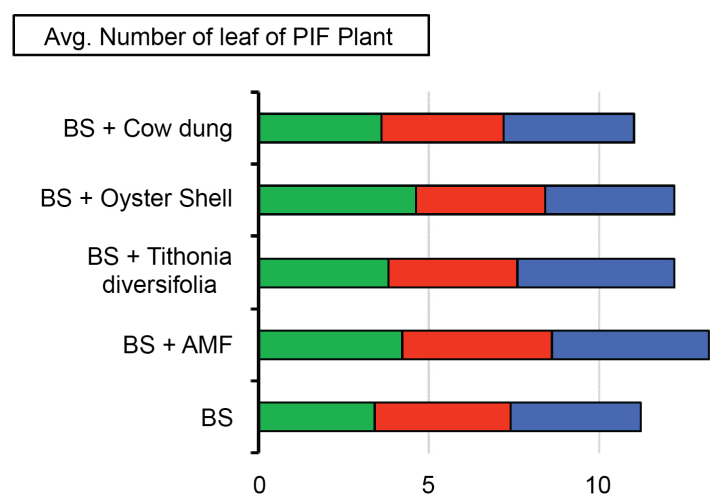

(e)

15

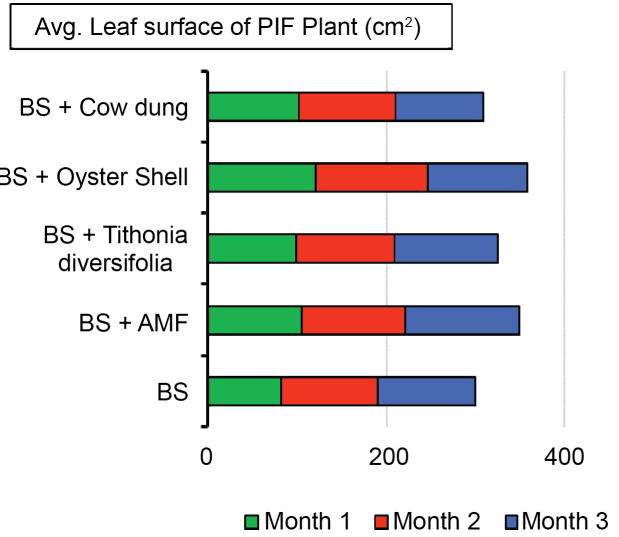

(g)

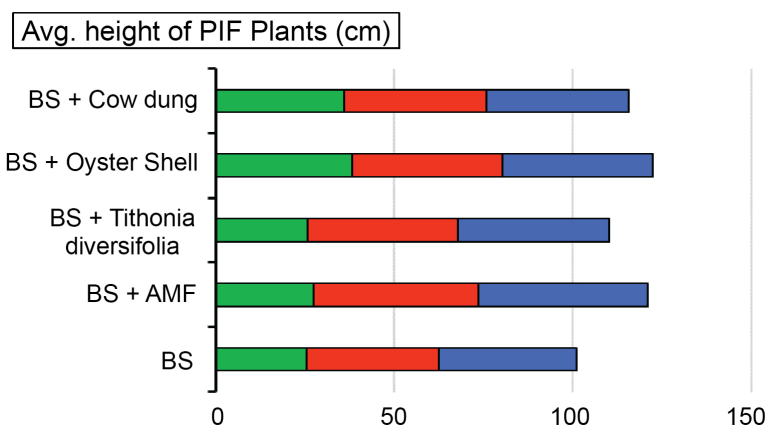

(b)

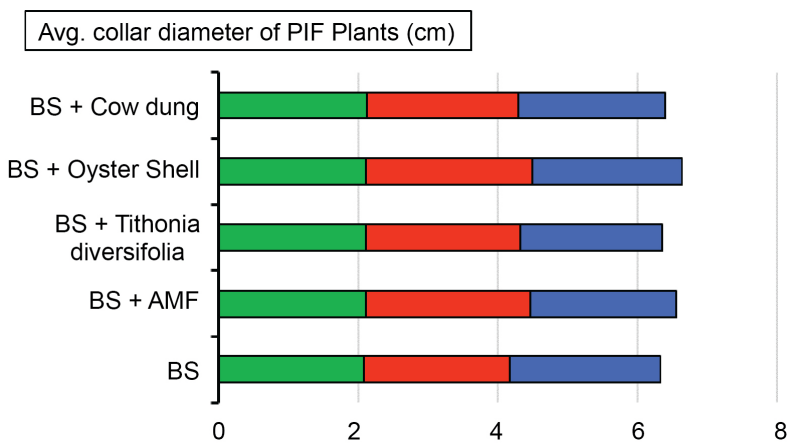

(d)

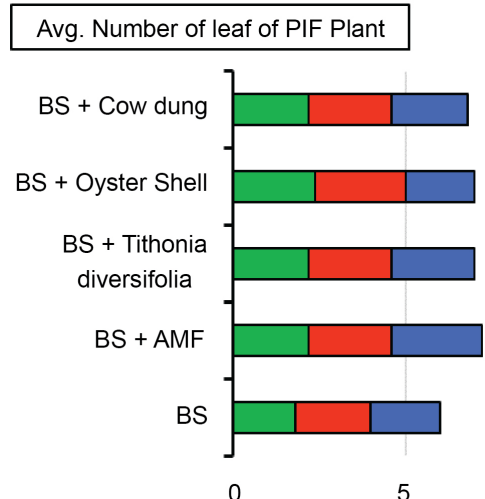

(f)

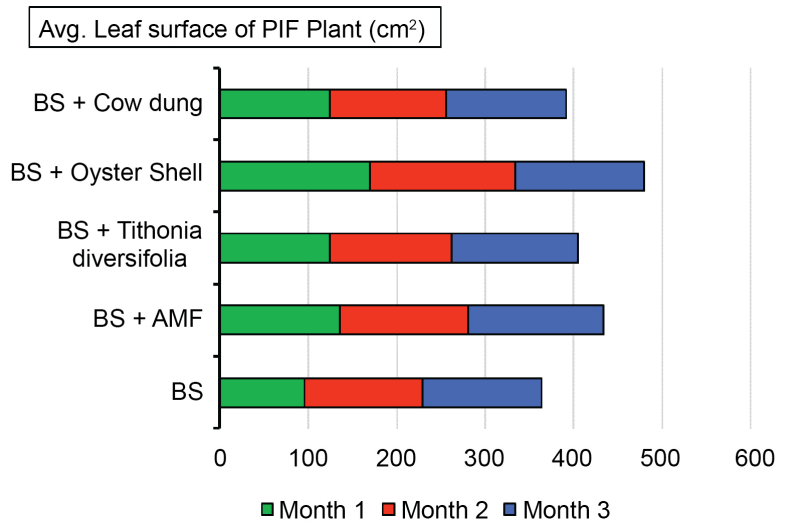

(h)

Figure 2. Evaluation of agronomic growth parameters in weaned PIF plants of the cultivars Makoumba (a), (c), (e) and (g) and Ehkwan'frè (b), (d), (f) and (h) of C. esculenta in acclimatization according to treatments applied during three months. Sterilized black soil (BS), arbuscular mycorrhizal fungi (AMF), average (Avg.). 


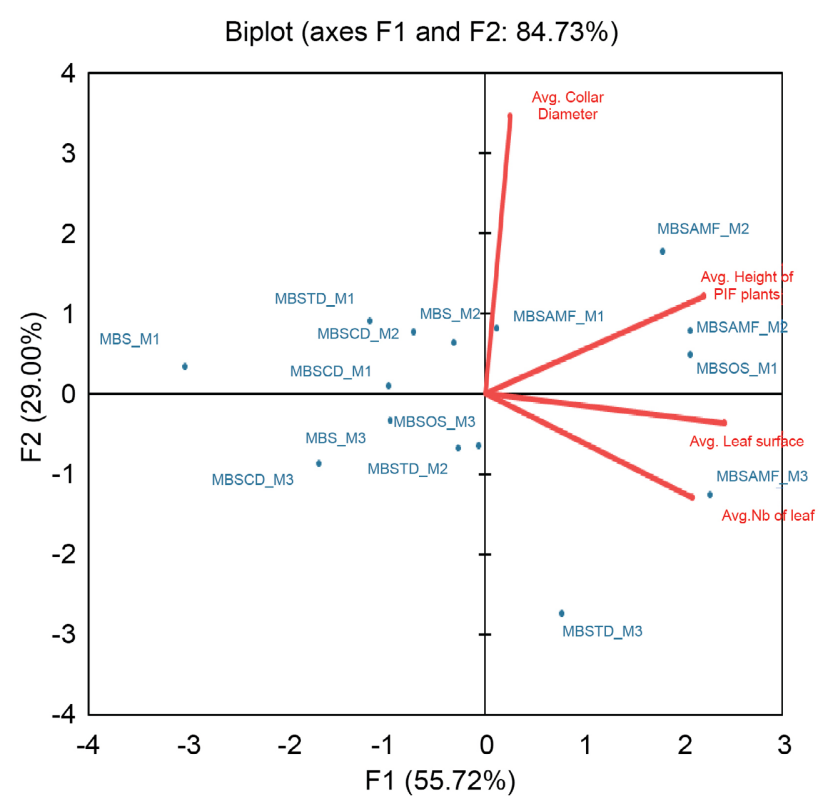

(a)

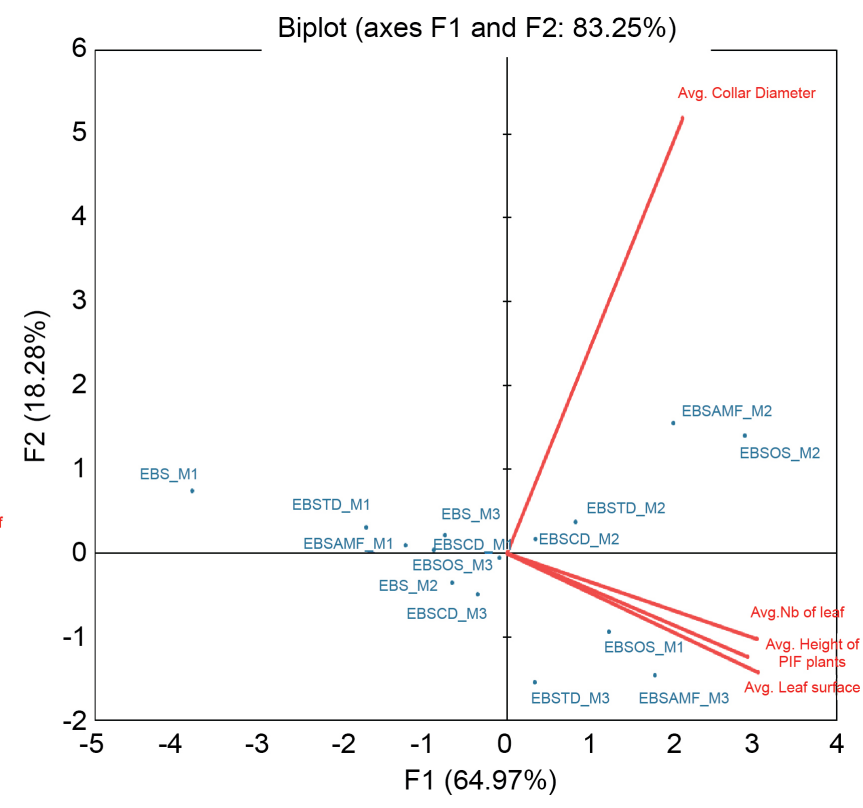

(b)

Figure 3. Principal component analysis (PCA) factorial plot of relative data on the effect of applied fertilizers on morphological growth parameters over time in the two cultivars of $C$. esculenta. Cultivar Makoumba (a) and Ehkwan'frè (b). Treatment applied to the Makoumba cultivar: Makoumba PIF plant in black soil (MBS); in black soil inoculated with AMF (MBSAMF); in black soil amended with Tithonia diversifolia (MBSTD); in black soil amended with Oyster shells ash of Crassostrea spp. (MBSOS); in black soil amended with cow dung (MBSCD). Treatment applied to the Ehkwan'frè cultivar: Ehkwan'frè PIF plant in black soil (EBS); in black soil inoculated with AMF (EBSAMF); in black soil amended with Tithonia diversifolia (EBSTD); in black soil amended with Oyster shells ash of Crassostrea spp. (EBSOS); in black soil amended with cow dung (EBSCD). M1 (Month 1), M2 (Month 2), and M3 (Month 3).

Table 4. Evaluation of the survival rate of PIF plants of $C$. esculenta in the two cultivars used according to the treatments applied during acclimatization.

\begin{tabular}{|c|c|c|c|c|c|c|}
\hline Cultivars & Treatments & $\begin{array}{l}\text { Number of } \\
\text { PIF plants } \\
\text { acclimated }\end{array}$ & $\begin{array}{l}\text { Number of dead } \\
\text { PIF plants }\end{array}$ & $\begin{array}{c}\text { Number of } \\
\text { surviving PIF } \\
\text { plants }\end{array}$ & $\begin{array}{l}\text { Acclimatization } \\
\text { success rate }(\%)\end{array}$ & $\begin{array}{c}\text { Acclimatization } \\
\text { mortality rate } \\
(\%)\end{array}$ \\
\hline \multirow{5}{*}{ Makoumba } & BS & 30 & 2 & 28 & 93.33 & 6.66 \\
\hline & $\mathrm{BS}+\mathrm{AMF}$ & 30 & 0 & 30 & 100 & 0 \\
\hline & BS + Tithonia diversifolia & 30 & 0 & 30 & 100 & 0 \\
\hline & BS + Oyster shells & 30 & 0 & 30 & 100 & 0 \\
\hline & BS + Cow dung & 30 & 0 & 30 & 100 & 0 \\
\hline \multirow{5}{*}{ Ehkwan'frè } & BS & 30 & 0 & 30 & 100 & 0 \\
\hline & $\mathrm{BS}+\mathrm{AMF}$ & 30 & 0 & 30 & 100 & 0 \\
\hline & BS + Tithonia diversifolia & 30 & 0 & 30 & 100 & 0 \\
\hline & BS + Oyster shells & 30 & 0 & 30 & 100 & 0 \\
\hline & BS + Cow dung & 30 & 0 & 30 & 100 & 0 \\
\hline
\end{tabular}

According to [20] this high $\mathrm{C} / \mathrm{N}$ ratio would indicate slow mineralization of carbon, slow decomposition of organic matter and consequently, immobilization 
of the nitrogen necessary for growth. Therefore, the recovery of dormant buds on both sides of the corm fragment would be the result of favourable growing conditions in the propagators that would not influence the water uptake by the osmosis phenomenon that would facilitate the hydrolysis of the starch chain stored in the starchy parenchyma of the corm fragment of each cultivar. Osmosis is a vital function for the growth and stability of plant life [21] [22]. Thus during the budding phase, in propagators with only sawdust + wood shavings as substrate, the carbohydrates needed for growth would be produced through the phenomenon of respiration which is responsible for the degradation of the starch chain contained in the corm fragments. Similarly, the presence of oyster shell ash of Crassostrea spp., an important source of chitin, rich in calcium $\left(\mathrm{Ca}^{2+}\right)$ and mineral elements in the substrate would have boosted bud development in both cultivars of Colocasia esculenta. This justifies the high values of the average number of buds emitted per plant and the total number of buds emitted in culture propagators with substrate + oyster shell ash of Crassostrea spp. treatment. Mineral element availability is a key to growth improvement [23] [24]. For all culture conditions, PIF plants from the emitted buds exhibited growth at different rates. Therefore, despite the destruction of apical dominance of the main bud at the beginning of cultivation, there would be apical dominance among the different emitted buds. This explains the significant difference between the number of PIF plants weaned in the first and second months of culture. The number of PIF plants produced decreased over time for all cultivars.

From 120 corm fragments of the both cultivars of C. esculenta, 599 PIF plants were produced and weaned. 246 PIF plants for Makoumba's cultivar and 353 PIF plants for Ehkwan'frè's cultivar. This allows us to say that the PIF technique allowed us to multiply the number of the fragments of corm used by 4.99 times. The results also show that the number of PIF plants weaned is higher after one month of cultivation. This could be justified by the availability of carbohydrates which would be the result of the hydrolysis of the starch chain present in the starchy parenchyma of the corm fragments. However, in the second month, a decrease in the number of PIF plants produced is noted. This could be due to the fact that after weaning, the PIF plants that were not weaned would continue to exert inhibition on the buds that did not quickly recover. It is noticed that the number of weaned PIF plants is higher in both cultivars when the fragments used were grown in the presence of Crassostrea spp. oyster shell ash, i.e. 140 and 200 PIF plants respectively for Makoumba and Ehkwan'frè cultivars after two weanings. Thus, since the wood substrate is organic matter that degrades slowly, the source of mineral matter needed for growth would come in part from the hydrolysis of the oyster shell ash used during the watering of the propagators.

The results of the analysis of agronomic growth parameters during the cultivation and production of PIF plants in the propagators showed that, in the two cultivars of $C$. esculenta used, the parameters, average of plant height, average of 
collar diameter, average of number of leaves and average of leaf surface were higher and significant $(\mathrm{P}<0.05)$ in the propagators fertilized with oyster shell ash of Crassostrea spp. This significant increase in the presence of oyster shells in the medium is characterized by the availability of mineral elements for the plant. In addition, the richness of oyster shells in $\mathrm{Ca}^{2+}$ and chitin would have played a significant role as $\mathrm{Ca}^{2+}$ is a crucial regulator of plant growth and development [17] [25] while the chitin present is a growth activator.

Fertilizers applied in PIF plants of both cultivars during acclimation influenced growth. Oyster shell ash of Crassostrea spp. and arbuscular mycorrhizal fungus (AMF) treatments had the greatest influence on growth, compared to Tithonia diversifolia leaf powder and cow dung powder applied. All these treatments indeed release mineral elements into the culture medium, except for the AMFs, which are soil microorganisms whose role is to feed the plant as a result of the established symbiosis. Therefore, the growth peaks observed in the presence of oyster shell ash of Crassostrea spp. during the first and second months of culture would be due to the immediate availability of mineral elements while in the presence of these AMFs, the peaks visible during the third month of culture would be the result of the establishment of the symbiosis.

\section{Conclusion}

The objective of this work was to carry out mass production of sanitized seedlings of two cultivars of $C$. esculenta widely cultivated in Cameroon by the method of PIF, while highlighting the aspect of fertilization of the production propagators from the ash of oyster shells (Crassostrea spp.) while evaluating the influence of some fertilizers during the growth of these PIF seedlings in acclimatization. The results obtained show that the use of the PIF method boosted the production of sanitized seeds of PIF plants in these C. esculenta cultivars. From 120 corm fragments of the two $C$. esculenta cultivars, 599 PIF plants were produced and weaned. This technique allowed a 4.99 -fold increase in the number of corm fragments. Furthermore, among the fertilizers used, the oyster shell ash Crassostrea spp. and arbuscular mycorrhizal fungus treatments had the most positive influence on growth during acclimatization. The mastery of the mechanisms of this technique would be an asset for their popularization among farmers.

\section{Acknowledgements}

The authors thank all the member of the Araceae Research Team of the Laboratory of Plant Physiology and Biochemistry, Department of Biological Sciences, Higher Teachers' Training College, University of Yaoundé I. Yaoundé, Cameroon. This research work was not funded.

\section{Conflicts of Interest}

The authors declare no conflicts of interest regarding the publication of this research work. 


\section{References}

[1] Nip, W.K., Muchille, J., Cai, T. and Moy, J.H. (1989) Nutritive and Non-Nutrient in Taro (Colocasia esculenta (L.) Schott) from American Samoa. Journal of Hawaii Pacific and Agriculture, 2, 1-5.

[2] Ahmed, A. and Khan, F. (2013) Extraction of Starch from Taro (Colocasia esculenta) and Evaluating It and Further Using Taro Starch as Disintegrating Agent in Tablet Formulation with Over All Evaluation. Inventi Rapid: Novel Excipients, 2, $1-5$.

[3] Misra, R.S., Sriram, S., Govil, J.N., Pandey, J., Shivakumar, B.G. and Singh, V.K. (2002) Medicinal Value and Export Potential of Tropical Tuber Crop. Crop Improvement Production Technology Trade and Commerce, 5, 376-386.

[4] FAOSATAT (2021) Food and Agriculture Organisation of the United Nations Statistical Database. Statistical Division, FAO, Rome. http://www.fao.org/statistics/en

[5] Otekunrin, O.A., Sawicka, B., Adeyonu, A.G., Otekunrin, O.A. and Rachon, L. (2021) Cocoyam [Colocasia esculenta (L.) Schott]: Exploring the Production, Health and Trade Potentials in Sub-Saharan Africa. Sustainability, 13, 4483. https://doi.org/10.3390/su13084483

[6] Owusu-Darko, P.G., Paterson, A. and Omenyo, E.L. (2014) Cocoyam (Corms and Cormels)-An Underexploited Food and Feed Resource. Journal of Agriculture and Chemical Environment, 3, 22-29. https://doi.org/10.4236/jacen.2014.31004

[7] Anonyme (2011) Note de conjoncture no 11, La production du taro menacée. MINADER, Cameroun.

[8] Manju, B.E., Mbong, A.G., Fokunang, N.C., Tembe-Fokunang, A.E. and Hanna, R. (2017) Application of In-Vitro Micropropagation Technique for Sustainable Production of Four Local Taro Cultivars [Colocasia esculenta (L.) Schott] in Cameroon. African Journal of Biotechnology, 16, 1638-1645.

https://doi.org/10.5897/AJB2017.15921

[9] Bello-Belloc, J.J., et al. (2020) An Efficient Protocol for Commercial Micropropagation of Malanga (Colocasia esculenta L. Schott) Using Temporary Immersion. Scientia Horticulturae, 261, 1-7. https://doi.org/10.1016/j.scienta.2019.108998

[10] Kwa, M. (1996) Etude des techniques de multiplication du matériel végétal in Vivo dans: Rapport technique, Doc. Interne, CRBP, Njombé, 96-100.

[11] Bonte, E., Verdonck, R. and Gregoire, L. (1995) La multiplication rapide du bananier et du plantain au Cameroun. Tropicultura, 13, 109-116.

[12] Kwa, M. (2002) Techniques horticoles de production de masse de plants de banane: La technique des plants issus de fragments de tige (PIF). Fiche technique CARBAP, 4 p.

[13] Ewané, C.A., Ndongo, F., Ngoula, K., Tene Tayo, P.M., Opiyo, S.O. and Boudjeko, T. (2019) Potential Biostimulant Effect of Clam Shells on Growth Promotion of Plantain PIF Seedlings (var. Big Ebanga \& Batard) and Relation to Black Sigatoka Disease Susceptibility. American Journal of Plant Science, 10, 1763-1788. https://doi.org/10.4236/ajps.2019.1010125

[14] Ewané, C.A., Milawé Chimbé, A., Ndongo Essoké, F. and Boudjeko, T. (2020) Influence of Clam Shells and Tithonia diversifolia Powder on Growth of Plantain PIF Seedlings (var. French) and Their Sensitivity to Mycosphaerella fijiensis. African Journal of Agricultural Research, 15, 393-411. https://doi.org/10.5897/AJAR2019.14486

[15] Young, H.L., Shah, M.D., Asraful, I., Sun, J., Kye, M.C., Renukaradhya, K.M., Jae, Y.H., Hoon, K. and Han, D.Y. (2010) Composted Oyster Shell as Lime Fertilizer Is 
More Effective than Fresh Oyster Shell. Bioscience Biotechnology and Biochemistry Journal, 74, 1517-1521. https://doi.org/10.1271/bbb.90642

[16] Téné, T.P.M., Dzelamonyuy, A., Omokolo, N.D. and Boudjeko, T. (2019) Enhancement of Theobroma cacao Seedling Growth and Tolerance to Phytophthora megakarya by Heat-Treated Oyster Shell Powder. American Journal of Plant Sciences, 10, 578-594. https://doi.org/10.4236/ajps.2019.104042

[17] Reddy, V.S. and Reddy, A.S.N. (2004) Proteomics of Calcium-Signaling Components in Plants. Phytochemistry, 65, 1745-1776.

https://doi.org/10.1016/j.phytochem.2004.04.033

[18] Benhamou, N. and Rey, P. (2012) Stimulateurs des défenses naturelles des plantes: Une nouvelle stratégie phytosanitaire dans un contexte d'écoproduction durable. II. Intérêt des SDN en protection des cultures. Phytoprotection, 92, 24-35. https://doi.org/10.7202/1013299ar

[19] Djeuani, A.C. (2009) Activation du système de défense chitosan et benzothiadiazole dépendant chez Xanthosoma sagittifolium L. Schott infecté par Pythium myriotylum. Mémoire de MASTER II. Université de Yaoundé I. 62 p.

[20] Bakayoko, S., Abobi, A.H.D., Konate, Z. and Toure, N.U. (2019) Effets compares de la bouse de bovins séchée et de la sciure de bois sur la croissance et le rendement du maïs (Zea mays L.) (AGRIEDAYS 2019). Agronomie Africaine, 8, 1-10.

[21] Broyer, T.C. (1947) The Movement of Materials into Plants Part I. Osmosis and the Movement of Water into Plants. The Botanical Review, 13, 1-58.

https://doi.org/10.1007/BF02861374

[22] Munns, R., Passioura, J.B., Colmer, T.D. and Byrt, C.S. (2020) Osmotic Adjustment and Energy Limitations to Plant Growth in Saline Soil. New Phytologist, 225, 1091 1096. https://doi.org/10.1111/nph.15862

[23] Barbosa, E.R.M., Tomlinson, K.W., Carvalheiro, L.G., Kirkman, K., de Bie, S., Prins, H.H.T., et al. (2014) Short-Term Effect of Nutrient Availability and Rainfall Distribution on Biomass Production and Leaf Nutrient Content of Savanna Tree Species. PLoS ONE, 9, e92619. https://doi.org/10.1371/journal.pone.0092619

[24] Chen, M.M., Zhang, S.R., Liu, L., Wu, L.P. and Ding, X.D. (2021) Combined Organic Amendments and Mineral Fertilizer Application Increase Rice Yield by Improving Soil Structure, P Availability and Root Growth in Saline-Alkaline Soil. Soil and Tillage Research, 212, Article ID: 105060.

https://doi.org/10.1016/j.still.2021.105060

[25] Tanveer, K., Gilani, S., Hussain, Z., Ishaq, R., Adeel, M. and Ilyas, N. (2020) Effect of Salt Stress on Tomato Plant and the Role of Calcium. Journal of Plant Nutrition, 43, 28-35. https://doi.org/10.1080/01904167.2019.1659324

\section{Abbreviations}

BS: black soil

AMF: arbuscular mycorrhizal fungus

TD: Tithonia diversifolia

OS: Oyster shells ash of Crassostrea spp

CD: cow dung 